\title{
Interrelation of geomorphology and fauna of Lavrado region in Roraima, Brazil - suggestions for future studies
}

\author{
Thiago Morato de Carvalho, Celso Morato de Carvalho
}

\begin{abstract}
How to cite:
CARvalho, T. M., CARvalHo, C. M. (2012): Interrelation of geomorphology and fauna of Lavrado region in Roraima, Brazil - suggestions for future studies. - E\&G Quaternary Science Journal, 61 (2): 146-158. DOI: 10.3285/eg.61.2.03

Abstract:

The authors discuss the relevance of geomorphology and biology interaction under the concepts of the Brazilian morphoclimatic domains. The discussion is focused on biogeographical and ecological aspects. The open areas of Roraima - the lavrado - localized between Brazil, Venezuela and Guyana, in the Northern portion of the Amazon morphoclimatic domain, is the region where the present case study was carried out. Remote sensing techniques were applied to determine the relief and field biology characterization. The generated products were useful for describing the habitats and local distribution of the lavrado's fauna.

Die Wechselbeziehung von Geomorphologie und Fauna in der Lavrado Region in Roraima, Brasilien: Vorschläge für zukünftige Studien

Kurzfassung:

In der vorgelegten Arbeit wird die Abhängigkeit von Geomorphologie und biologischen Interaktion unter Verwendung des Konzeptes morphoklimatischer Regionen Brasiliens vorgestellt. Die Diskussion fokussiert hierbei auf biogeographische und ökologische Aspekte. Die vorgelegte Studie wurde in den offenen Bereichen von Roraima - Lavrado - zwischen Brasilien, Venezuela und Guyana durchgeführt. Dieses Gebiet liegt im nördlichen Teil der morphoklimatischen Region Amazoniens. Zur Anwendung kamen Techniken der Fernerkundung, um das Relief der Region zu ermitteln und biologische Charakterisierungen durchzuführen. Die hierdurch erzielten Ergebnisse wurden genutzt, um Lebensräume der Region und die Verteilung der Lavrado Fauna zu beschreiben.
\end{abstract}

Keywords: $\quad$ Biogeomorphology, Amazon morphoclimatic domain, Roraima, lavrado

Addresses of authors: Thiago Morato de Carvalho*, Celso Morato de Carvalho**, National Institute of Amazonian Research (Instituto Nacional de Pesquisas da Amazônia - INPA) Boa Vista, Roraima, Brazil. ZipCode 69301-150. *tmorato@infonet.com.br; ${ }^{* *} \mathrm{cmorato@inpa.gov.br}$

\section{Introduction}

On a geomorphological viewpoint, the Amazon rainforest can be characterized by its lowland relief and extensive forested areas, by the dichotomy between main allochthonous and small autochthonous rivers, as well as combining latosol and podzol low fertility soils. The annual thermal range is relatively homogeneous, $24^{\circ} \mathrm{C}$ to $26^{\circ} \mathrm{C}$; the rainfall is heterogeneous, 1750 to $2300 \mathrm{~mm} /$ year, outside the Andes, which is around $7000 \mathrm{~mm} /$ year; and the vegetation is a complex net distributed over periodically flooded forest and upland, várzea and terra firme respectively (VICTORIA et al. 2000; AB'SABER 2003). These combined geomorphological features form an area of approximately 7 million $\mathrm{km}^{2}$, called the Amazon morphoclimatic domain. What in Brazil we call a morphoclimatic domain is an area of sub-continental dimensions, with characteristic patterns of relief, drainage, climate, soils and vegetation (Ав'SABER 1967).

One important feature of the Amazon morphoclimatic domain is the physiognomy of its vegetation, which can be open (scrubs, herbs and small trees) or closed (tall trees, with some emerging). Taking only this aspect into account, the open areas that occur in the Amazon region can be quite similar to those occurring in other domains, for example, the open vegetation of cerrado in the Central Brazilian ecosystem, the Bolivian Chaco or the lhanos in Venezuela. However, there are many ecological and physiological differences between these open formations, such as floristic composition, soil formation, geomorphological genesis, drainage and climate (VANZOLINI \& CARVAlHo 1991; EITEN 1992, 1994).

We can focus on this physiognomic dichotomous property of the Amazon vegetation with different lenses, depending of the goal. From the biogeographical viewpoint, for instance, these two morphological aspects of vegetation, open and closed areas, are important for understanding the distribution of organisms, principally when we consider the pulsation of the forest over the last 20.000 years - the open areas entering the forest during the Pleistocene glacial dry periods and the expansion of the forest during the interglacial wet periods throughout South American ecosystems (VANZOLINI 1988; Ав’SABer 1977; Pessenda et al. 2009).

In the Brazilian Amazon there are expressive open veg- 


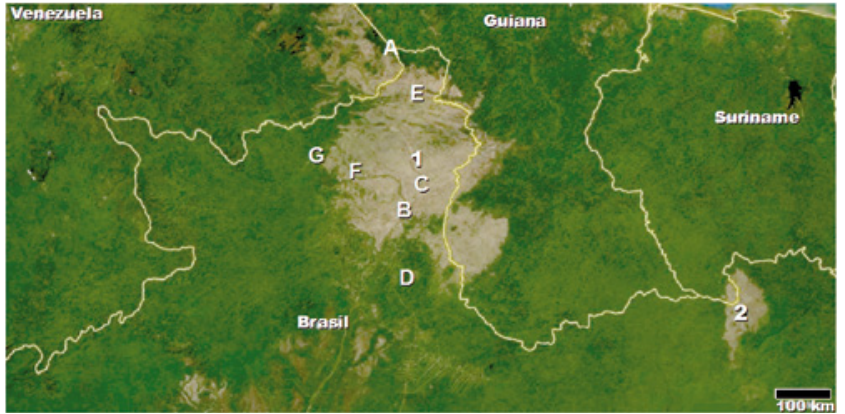

Fig. 1: Examples of open areas within the Amazon morphoclimatic domain 1 - Roraima, Venezuela and Guyana. 2 - Amapá state, Brazil. A - Monte Roraima; B - Branco River; C - Lacustrine Systems; D - Serra da Lua; E Serra Marari; F - Maracá Island; G - Serra do Tepequém.

Abb. 1: Beispiele von Freiflächen innerhalb der morphoklimatischen Region Amazonas. 1 - Roraima, Venezuela und Guyana. 2 - Bundesstaat Amapá, Brasilien. A - Monte Roraima; B - Branco River; C-Lacustrine Systems; D - Serra da Lua; E - Serra Marari; F - Maracá Island; G - Serra do Tepequém.

etation areas in the states of Pará, Amapá and Roraima, occurring as enclaves inside extensive forested areas (MURÇAPires 1974; CARvalho 2009; VAnzolini 1992) and along the major rivers, such as the Trombetas (EgLER 1960), Negro (DUCKe \& BlaKe 1953), in the mouth of the Tapajós (RADAMBrasil 1975) and in the Madeira (MurçA-PIRES 1974). These open areas comprise several landscapes, such as plains, plateaus, hills and mountains. Associated with these geomorphological features there occur the scrubs, herbs, grasses and cactacean adapted to these physical formations, constituting very particular habitats where can live and reproduce different species of animals.

The most relevant fact concerning the distribution of animals and plants is that they are not randomly distributed along their areas of occurrence; on the contrary, there are specific habitats where they can live. In this way, it is our thought that: i) biological aspect concerning the distribution of organisms among the various habitats that form ecosystems cannot be understood without the understanding of the physical structure of these habitats, ii) this comprehension can be given by a geomorphological approach.

The rational of our thought is tied to the concepts establishing that the distribution of organisms reflects their sets of adaptations to the immediate environment, a concept known as ecological niche (VANZOLINI 1970; PiAnKA 1994). This idea is the soul of classical studies approaching biology (zoogeography) and geomorphology, which were carried out by VANZOLINI \& Williams (1970), VANZOLINI (1970, 1981) and AB'SABER (1967), currently incremented by news geoprocessing techniques (CARvAlHo $\mho$ RAMIREZ 2008; CARVALHO 2009a; METZGER 1997).

In this context, the aim of the present study is focused on the landscape and habitats that occur in open areas inside the Amazon region. The scenario of this discussion encompassing the field of biogeomorphology comprises three ways: i) concepts of morphoclimatic domains and biogeography, ii) the case study of a very interesting open area known as lavrado, situated in the Northern Amazon region - the Brazilian state of Roraima, iii) use of geoprocessing techniques for identifying and describing habitats.

\section{The case study area}

The general region described in this report (Fig. 1), comprised in the Guyana Shield (HAmmond 2005), is a very peculiar open area of some $69.000 \mathrm{~km}^{2}$, mostly situated in the northern portion of the Amazon morphoclimatic domain, overlying three countries. We estimate, by remote sensing, that this area covers some $45.000 \mathrm{~km}^{2}$ in the Brazilian state of Roraima, $10.000 \mathrm{~km}^{2}$ in Venezuela and $14.000 \mathrm{~km}^{2}$ in Guyana.

In Venezuela this portion of open areas is about 1200-1600 meters above sea level. It is characterized by the presence of ruiniform tabular mountains, individually called tepuy. The tepuyes are part of a geomorphological formation known in Venezuela as Gran Sabana. In the Brazilian territory the best known tepuy is the Roraima Mount (05¹1'S, 609'W), around 2800 meters high, situated on the triple border of Brazil, Venezuela and Guyana. We do not consider this Venezuelan region to be part of the Amazon morphoclimatic domain (see AB'SABER 2003).

In the Guyana region this Northern Amazon open area is mostly situated on the basin of the Rupununi River, an affluent of the main Guyanese river, the Essequibo. This open area, locally known as Rupununi Savanna, is separated by the Tacutu River. This river, that forms the border of Brazil and Guyana, runs in a geological fissure from South to North, where it turns westward to flow into the Uraricoera River in Brazil (approximately at $03^{\circ} 01^{\prime} \mathrm{N}, 60^{\circ} 28^{\prime} \mathrm{W}$ ), both rivers forming the Branco, which flows southward into the Negro River in the Brazilian state of Amazonas.

In the Brazilian portion, the state of Roraima, this area is known as lavrado, an old Portuguese term for open vegetation (VANZOLINI \& CARVAlHo 1991; CARVAlHo 2009). The lavrado has its own socio-cultural and ecological identity, integrated by complex networks of interactions among the local people with the landscape, and by a characteristic local fauna and flora adapted to the lavrado ecosystem (NASCIMENTO 1998).

This open area is formed by peculiar geomorphological features, such as boulders, alluvial plains, lakes and gallery forests along the rivers. Isolated patches of forest, scrubs and herbs, are present throughout the area. Gallery forests occur in the banks of the rivers. These features form the lavrado habitats, harboring many species of plants and animals, whose biological aspects of their distribution along these regional habitats are also focused in this study.

\section{Material and Methods \\ 3.1 Geomorphology}

To describe the morphology of the case study relief we used remote sensing techniques (hypsometry, shaded relief, topographic profiles and RGB composition) from elevations model of SRTM (Shuttle Radar Topography Mission) and Landsat 5 images. The elevation model from SRTM is a radar image, acquired by interferometry method in 2001 for entire globe, used for geomorphometrics analysis of the terrain.

The software ENVI 4.3 was used to resize the SRTM data to 30 meters, by interpolation, from original spatial resolution of 90 meters. This digital elevation model was important to identify the different altimetry values, and the morphology of denudation forms (ranges and hills) using shaded re- 

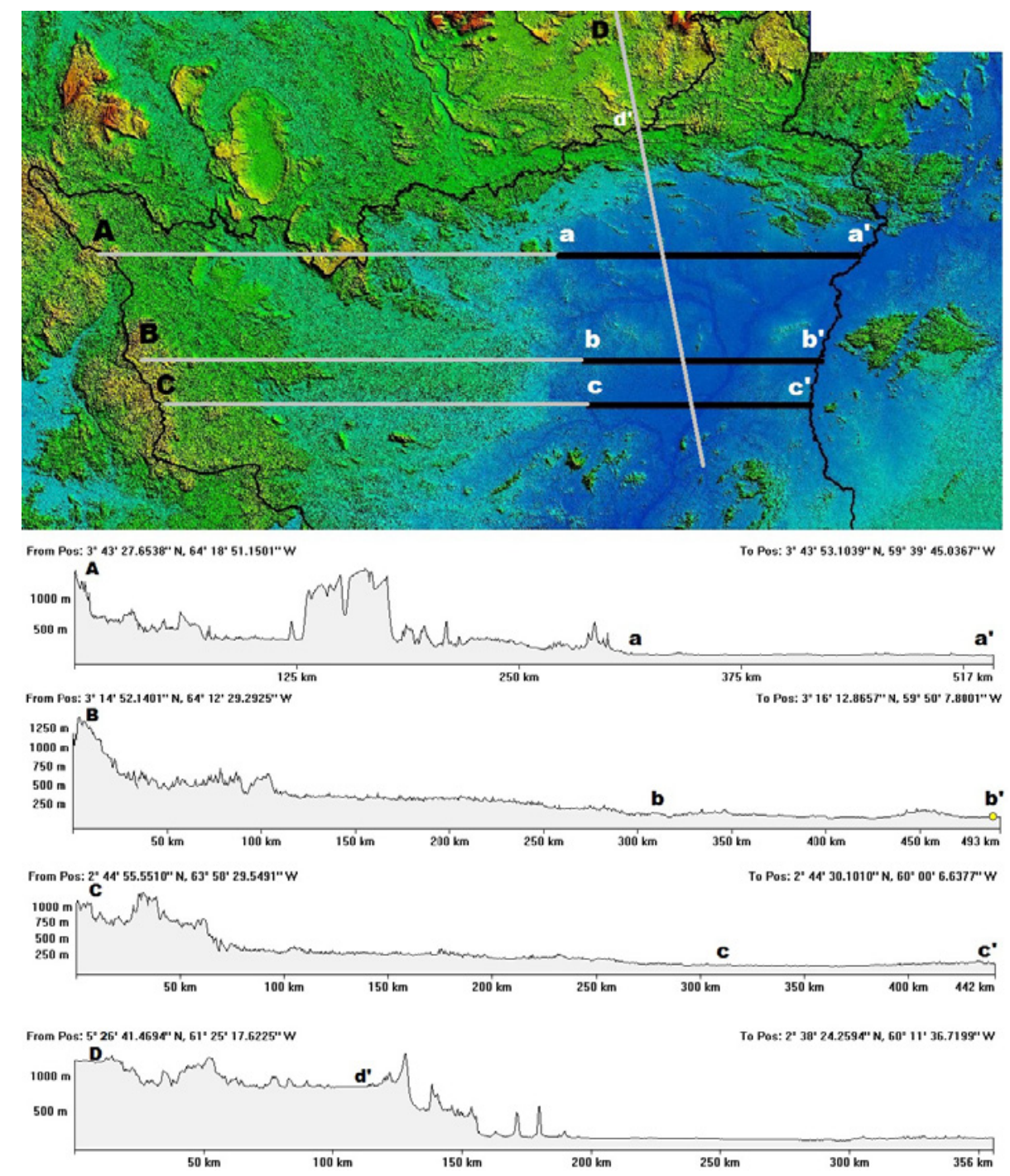

Fig. 2: Roraima, topographic transects profiles a-a' to c-c'; Venezuela - Roraima, transect D.

Abb. 2: Roraima, topographische Transekte a-a' to c-c'; Venezuela-Roraima, Transekt D.

lief and topographic profiles techniques. The optical images of Landsat 5 are mostly used for environmental studies, with 30 meters spatial resolution, and were used for identifying agradational morphologies, like fluvial plains, lakes and vegetation aspects by visual interpretation.

The Landsat 5 images RGB composition was applied in ENVI 4.3, using bands 5,4 and 3. The Landsat 5 images were achieved in 2005, from December to April, which corresponds to dry season (without clouds), patch-rows were 232(56,57,58); 231(57,58). These images were acquired at the National Institute of Spatial Research (INPE) - www.dgi. inpe.br/CDSR/ - and Embrapa Relevo - www.relevobr.cnpm. embrapa.br/.

\subsection{Fauna examples}

Case study of faunal elements, in the present context, were determined through field work conducted by the Instituto Nacional de Pesquisas da Amazônia (National Institute of Amazonian Research - INPA) in Roraima throughout the past two decades, mainly on the lavrado area (see CARvALHO
2009). We take as examples the vertebrate fauna of the area, mainly aspects of its distribution along the habitats comprised by geomorphological features determined through geoprocessing techniques (Figures 8, 9, 10).

\section{Results and Discussion 4.1 Geomorphological features of the lavrado: remote sensing}

One can see the position and topographic profile of the $l a-$ vrado and adjacent forested areas just looking at the region through transects, for example covering the forests of the West portion of Roraima up to the open areas in the East, or covering part of the Venezuelan Gran Sabana, until the lavrado areas (Fig. 2). At the same way, through transects (Fig. 3) we can see the main features of the relief, like high altitudes (more than 1500 meters high), with tabular relief (tepuys), agradational and denudational processes, moderated dissection and low structural control (Fig. 3 "1"); intermediary altitude, somewhat of 500-1500 m, with denudational processes, high dissection and strong structural con- 

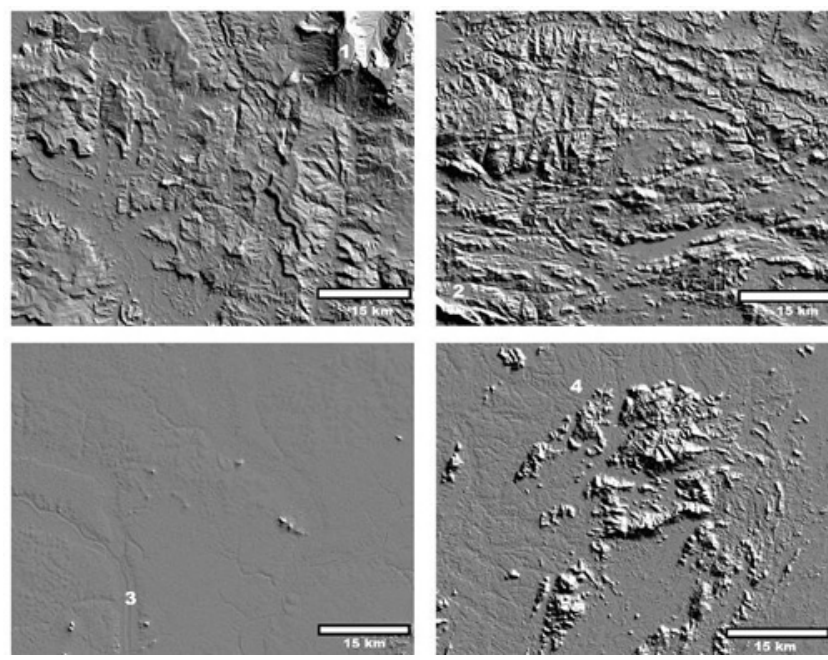

Fig. 3: 1 - Mount Roraima, moderate relief dissection, border of Venezuela and Brazil ( $\left.05^{\circ} 11^{\prime} \mathrm{N}, 60^{\circ} 49^{\prime} \mathrm{W}\right) ; 2$ - Serra Marari, moderate to strong dissected relief $\left(04^{\circ} 16^{\prime} \mathrm{N}, 60^{\circ} 46^{\prime} \mathrm{W}\right)$; 3 - Uraricoera River, low relief dissection $\left(03^{\circ} 19^{\prime} \mathrm{N}, 60^{\circ} 25^{\prime} \mathrm{W}\right) ; 4$ - Serra da Lua, low and strong relief dissection $\left(02^{\circ} 27^{\prime} \mathrm{N}, 60^{\circ} 28^{\prime} \mathrm{W}\right)$

Abb. 3: 1 - Mount Roraima, moderate Reliefzergliederung an der Grenze $z u$ Venezuela und Brasilien (05 $\left.11^{\circ} \mathrm{N}, 60^{\circ} 49^{\circ} \mathrm{W}\right) ; 2$ - Serra Marari, mäßige bis starke Reliefzergliederung $\left(04^{\circ} 16^{\circ} \mathrm{N}, 60^{\circ} 46, W\right) ; 3$ - Uraricoera River, niedrige Reliefzergliederung $\left(03^{\circ} 19^{\circ} \mathrm{N}, 60^{\circ} 25^{\circ} \mathrm{W}\right)$; 4 - Serra da Lua, niedrige und starke Reliefzergleiderung $\left(02^{\circ} 27^{\circ} \mathrm{N}, 60^{\circ} 28^{\circ} \mathrm{W}\right)$.

trol (Fig. 3 “2”); low sedimentary plains, around 70-100 m, with agradational processes like fluvial plains and lacustrine systems (Fig. 3 “3”); and isolated hills, inselbergs, with structural control (Fig. 3 "4").

In contrast with the high elevation of the Venezuelan Gran Sabana, the elevation of the lavrado area is relatively low, around 70-200 $\mathrm{m}$ a.s.l. This area is drained by the Branco River, which is composed by a system of low hills, with low dissected relief, isolated residual peaks (inselbergs), surrounded by lakes in the headwaters, the flowing of which creates a interconnected streams (igarapés) separated by small elevations, known as tesos, forms drainage dissection around the lakes and streams (Fig. 4). Also we can see in the area the sugar-loaf formations (pão-de-açucar) and laterite layers exposed on the soil (lajeiro).

In all lavrado areas narrow lines of palm trees remind one of the landscapes of the morphoclimatic domain of the Central Brazil cerrados. Of course this resemblance is only apparent, since the cerrado is a very distinct ecosystem, situated a few thousands kilometers from the lavrado. The reconnaissance of the distinctiveness between both ecosystems - lavrado and cerrado - has a very important ecological and biogeographical significance (EITEN 1963; CoutinHo 1978; Vanzolini \& Carvalho 1991; Carvalho 2009).

The predominant declivity of the lavrado is between $5^{\circ}-8^{\circ}$, with low energy, forming a region that receives sedimentary material, mainly sand coming from the surrounding crystalline uplands (Guyana Shield). The lavrado central portion's relief low energy favors the formation of a complex lacustrine system, composed by more or less circular up to 300 meters long lakes, most of which are temporary (Fig.5). These lakes are independent, interconnected by narrow streams, forming dendritic, rectangular and subdendrit-

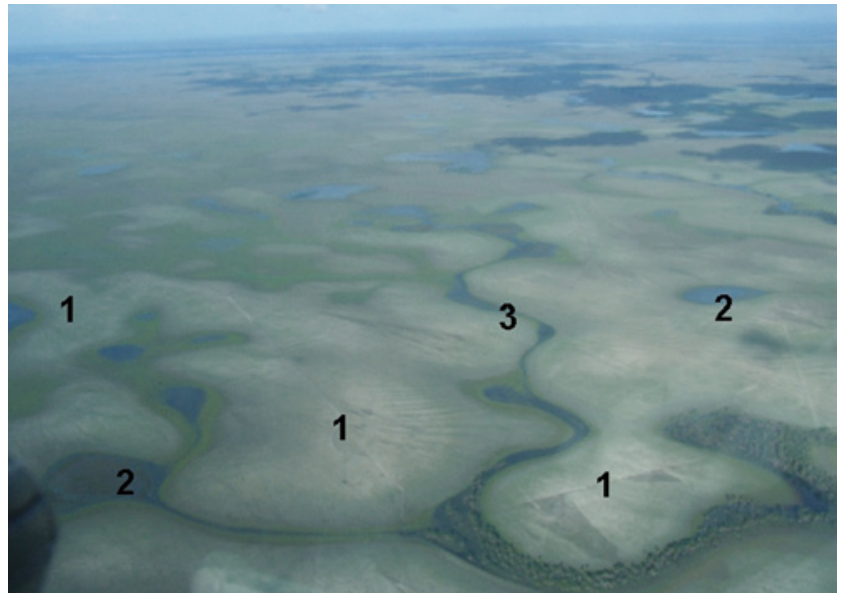

Fig. 4: 1 - Tesos (low hills) convex morphologies; 2 - lakes; 3 - small elevations between the streams.

Abb. 4: 1 - Tesos (flaches Hügelland) konvexe Morphologie; 2 - Seen; 3 kleine Erhebungen zwischen den Strömen.

ic patterns. These lakes are fed by ground water and resemble the lakes of the morphoclimatic domain of the cerrado (CARvalho \& Zucchi 2009). Figures 6-7 show some aspects of the fluvial plain and vegetation of the lavrado.

The rivers that cross the lavrado are autochthonous, with its headwaters in the elevated serras that make the border of Brazil and Venezuela, the Parima-Pacaraima system. The lavrado drainage, formed by well developed fluvial plains, is directed to the Negro River, which runs from the Andes until its confluence to the Solimões River, in the Central Amazon Basin. The main rivers that run in the lavrado have banks (dique marginal) and beyond these a formation called várzea, a floodplain area formed along the main rivers during the rainy season.

The vegetation of the lavrado is composed by interesting formations (BEIGBEDER 1959; Aв'SABER 1997). Throughout this open area one can see near 8-10 meters height and less than 0.5 ha, wood patches, surrounded by grouped or more disperse scrubs and small trees. The ground is covered by grasses and grass-like plants (family Cyperaceae). Lines of palm trees (Mauritia flexuosa), known as buritizais, due to the popular name buriti (family Palmae) for the palm tree, is an important element of the lavrado landscape, starting in small lakes and running toward the main rivers, for a distance of around 300-800 meters. The lavrado is surrounded by 15-20 meters high forest, soil with shallow litter, some emerging trees and somewhat unstructured understory.

\subsection{Geomorphology and fauna 4.2.1 The approach}

We can look at this interaction between geomorphology and biology from the point of view of different related areas of knowledge. Whatever the area, the main idea of this interaction is focused on species and populations distribution, local or along large areas. On the regional distribution, one may be interested in describing the species richness between habitats within an ecosystem, to understand aspects of the local biodiversity. On the other hand, we can focus on the distri- 


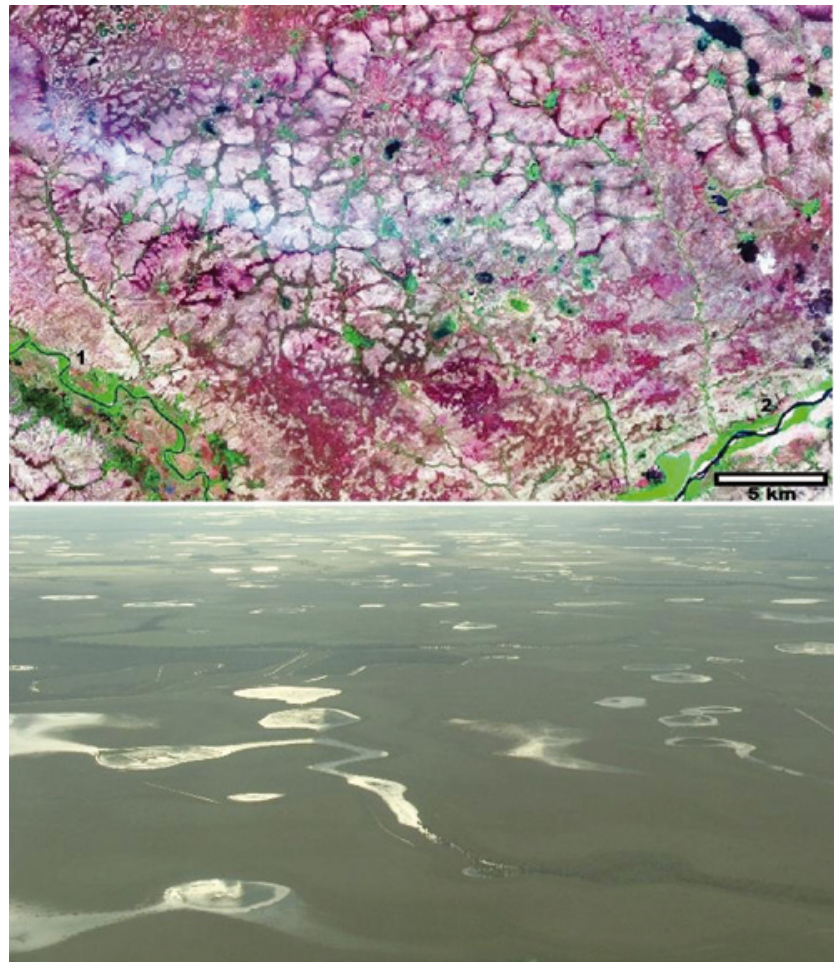

Fig. 5: Lacustrine system $\left(03^{\circ} 37^{\prime} \mathrm{N}, 60^{\circ} 15^{\prime} \mathrm{W}\right)$;

1 - Surumu River; 2 - Tacutu River

Abb. 5: Lakustrines System $\left(03^{\circ} 37^{\circ} \mathrm{N}, 60^{\circ} 15^{ } \mathrm{W}\right)$;

1 - Surumu River; 2 - Tacutu River.

bution of species and populations among ecosystem, in order to understand extensive distribution patterns, for example, populations in contact or separated by geomorphic barriers that have occurred in the present or past events.

Two emeritus herpetologists together with one geologist were the first to approach geomorphology to biology in 19691970. The zoologists are the Brazilian scientist Paulo Emílio Vanzolini and his North American colleague Ernst Williams. They have formulated a very elegant South American lizard (genus Anolis, family Polychrotidae) speciation model based on forest expansion and retraction, paleoclimatic events that occurred under the influence of the Pleistocene dry and wet periods over the past $20.000-10.000$ years.

This model of speciation formulated by VANzoLINI $\&$ Williams (1970) establishes that because of the forest fragmentation occurring during paleoclimatic dry periods (glaciation) animals became isolated in forests patches, which resulted in ecological barriers - forest species do not live in open areas. These barriers, in turn, determined the interruption of gene flow between populations. Dry events of the past can be inferred at present by geomorphologic features, such as the stone-lines (paleosols formed in dry paleoclimatic periods and buried in sedimentary deposits), indicating that a forested area today was open in the past (AB'SABER 2003; Hiruma 2007). Another way to infer past dry events is through palynological records and ${ }^{14} \mathrm{C}$ dating of sediments (Absy 2000; SAlgado-Laboriau 1982).

During the humid phase (interglacial) the forest coalesced and what was fragmented forest became continuous forested area; however, many animal species did not change gene again, because their populations were isolated for a period in which several biological and physiological changes occurred in each one. The result of these processes was the formation of distinct species. The model focused mainly on the pulsation of the forest in the Amazon region; however, the idea was applied for other regions and species (VANZOLINI 1988, 2002; WüsTER et al. 2005).

Following another way of the same theme, the German geologist Jürgen Haffer studying Amazonian birds, in 1969 came to the same conclusion and model of speciation as did Vanzolini and Williams for lizards in early 1970. This model of speciation, taking geomorphological evidences of expansion and retraction of the forest, became classic in biogeography and is well known as Pleistocene Refugia Model and Refugia Theory (VAnzolini 1970; Absy et al. 1991; Haffer \& Prance 2001; Haffer 1969; Ab’SABer 1982).

The morphoclimatic domains concepts, adopted by Vanzolini and Williams as vegetation criteria for their study of species distribution and refuges, were first formulated by Aziz Nacib Ab'Saber in 1967. Prior to this Brazilian geographer and geomorphologist, the vegetation of the regions in Brazil was identified through fragmented floristic features. The model of Ab'Saber gave the necessary strength in identifying large vegetal formations, instead of patches inside the same ecological and geomorphologic formation. Ab'Saber used the climate, vegetation, soil, Hydrography and relief as features to recognize what he called the area "core" in a domain, in a sub-continental scale. All kinds of regional geomorphological facies could, then, be included in one domain or another - cerrado, caatinga, mata atlântica and hiléia (the Amazon) - recognizing the transitional zones.

The model formulated by Ab'Saber was a great advance to the fields of geography and geomorphology, since regions could then be identified as a continuous unit with related geomorphologic features. To biologists interested in ecology and biogeography this geomorphologic model integrated formerly scattered data, enabling one to come to a better understanding of species distribution.

\subsection{Habitats and faunal distribution: the lavrado}

All those geomorphological formations comprised in the lavrado, such as hills, rock outcrops, lakes, small patches of forest, scrubs and the gallery forests along the rivers, with the back-swamps (várzea) of the major ones, form the habitats inhabited by many organisms. Identifying these habitats is the first step to comprehend the biology of any species that live in the lavrado, in terms of adaptations and gene flow among individuals and populations. Some geomorphological features can illustrate this point of view, such as the granite and laterite extrusions, hogbacks, inselbergs and sparse or grouped boulders at various sizes (matacões) in the plain and low hills present in the lavrado (Ruellan 1957). In addition to the geomorphological interpretation, these formations also have their ecological identity, forming complex microhabitats inhabited by birds, bats, rats, snakes, frogs, lizards and many species of invertebrates (VANZOLINI \& CARVALHO 1991; Carvalho 2009; Nunes \& Bobadilha 1997; RAFAel et al. 1997).

The rocks are distributed throughout the area and are directly exposed to the sunlight. These features led to many relevant biological questions, such as: How many species of vertebrates and invertebrates are associated with these 

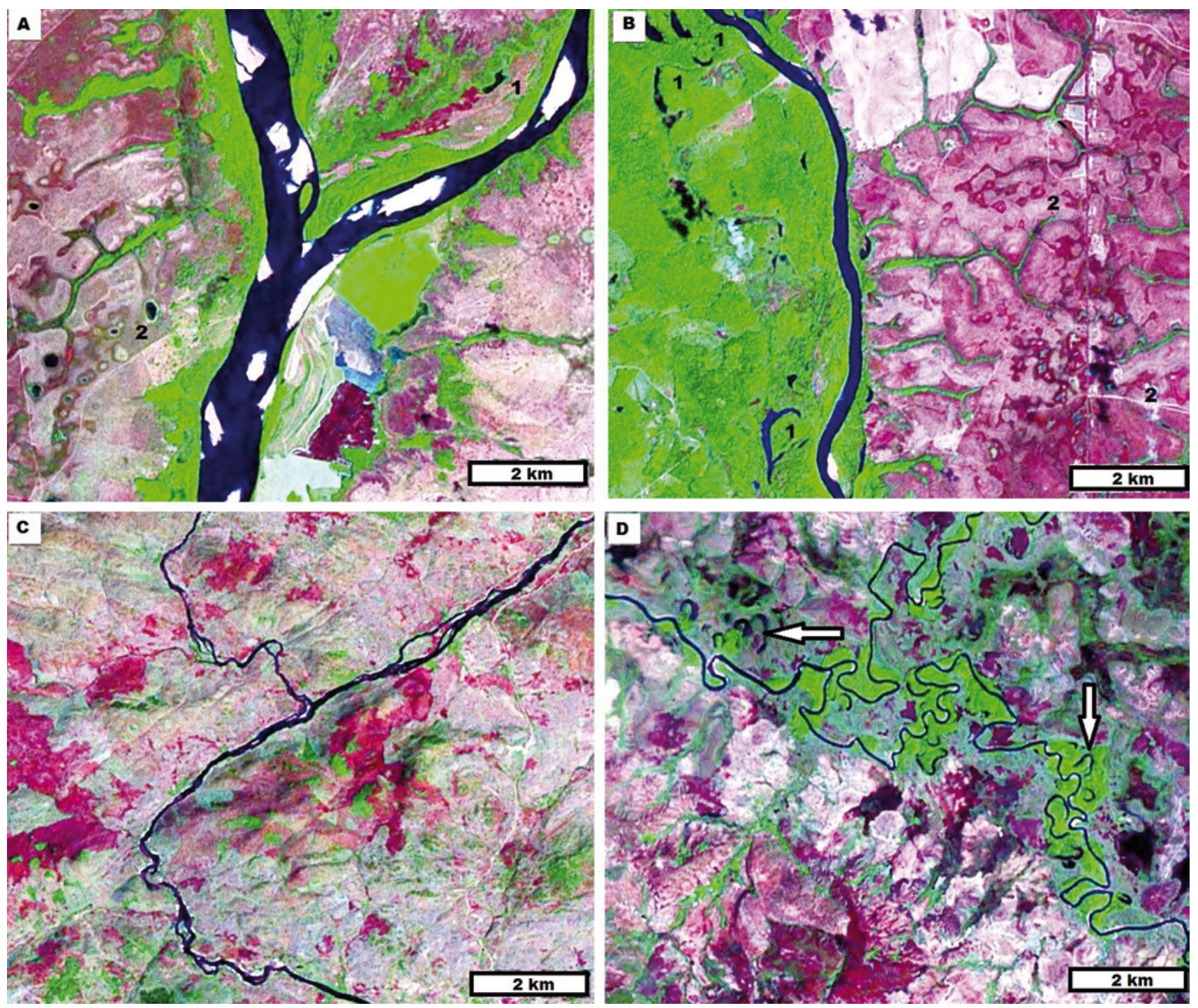

Fig. 6: “A-B”- fluvial plains, lowlands ( $03^{\circ} 01^{\prime} \mathrm{N}, 60^{\circ} 29^{\prime} \mathrm{W}$ and $\left.02^{\circ} 36^{\prime} \mathrm{N}, 60^{\circ} 54^{\prime} \mathrm{W}\right)$; “C-D” - fluvial plains, highlands $\left(04^{\circ} 17^{\prime} \mathrm{N}, 60^{\circ} 32^{\prime} \mathrm{W}\right.$ and $\left.04^{\circ} 56^{\prime} \mathrm{N}, 61^{\circ} 14^{\prime} \mathrm{W}\right)$. 1 - abandoned chanel lakes of flood plain; 2 - Lakes of flat plain. A - Mouth of the Tacutu River in the Branco River; B - Mucajai River; C - Cotingo River with structural control, non flood plain; D - meandriform river developed at structural control, small flood plain with lacustrine systems (oxbows lakes).

Abb. 6: “A-B" - Flussniederungen, Tiefland $\left(03^{\circ} 60^{\circ} \mathrm{N}, 29^{\circ} 01^{\circ} \mathrm{W}\right.$ und $\left.02^{\circ} 36^{\circ} \mathrm{N}, 60^{\circ} 54^{\circ} \mathrm{W}\right)$; “ $\mathrm{C}-\mathrm{D}^{\mathrm{c}}$ - Flussniederungen, Hochland $\left(04^{\circ} 17^{\circ} \mathrm{N}, 60^{\circ} 32^{\circ} \mathrm{W}\right.$ und $04^{\circ} 56^{\circ} \mathrm{N}$, $\left.61^{\circ} 14^{\prime} \mathrm{W}\right) .1$ - aufgegebene Kanalseen der Flussaue; 2 - Seen der Tiefebene. A - Zusammenfluss von Tacutu in den Brancoss; B - Mucajaí; C - Cotingo, nicht zur Flussaue entwickelt; D - mäandernder Fluss, kleinflächige Flussaue mit lakustrinen Systemen (Altwasserseen).

habitats? How many diet and reproductive adaptations have these species undergone so as to be able to survive in these geomorphological units? How can be genetically characterized the populations of the same species inhabiting the lavrado? There are any preferences of some particular species in residing certain geomorphological features, such as granite and laterite? How these rock outcrops are distributed (grouped or dispersed) and how to interpret the distribution pattern?

An interesting case of animal distribution in these granite habitats come from the frog Leptodactylus myersi, a species that seems to be endemic to the lavrado, living on the rocks, at least the main populations (HEYer 1995). Each population of this frog seems to be separated by several kilometers, which is the distance between the boulders. Questions based on this example may include: How are these frog populations distributed, taking into account they are directly associated with the boulders distribution? How to characterize the adaptations of this frog, in terms of reproduction and diet? Where they lay their eggs, considering the extreme exposure to this habitat to sunlight and dry environments? These are questions being currently studied.

Another species very common in the rock formations of the lavrado is the lizard Tropidurus hispidus (family Tropiduridae). The biological questions that can be applied to the populations of this lizard are associated with the habitats where they live, such as the boulders, small trees, border of the forest and in the small patches of forest. For example: Do all these lizards have the same set of adaptations? Is it possible to determine the populations of this lizard precisely by identifying the habitats through geoprocessing techniques?

Among mammals there are some interesting distribution in habitats composed by lacustrine system in general, low hills and dissected relief, vegetation of the margins of rivers (mata ciliar) and lines of palm trees (buritizais), laterite layers (lajeiros) and boulders. All these geomorphological 


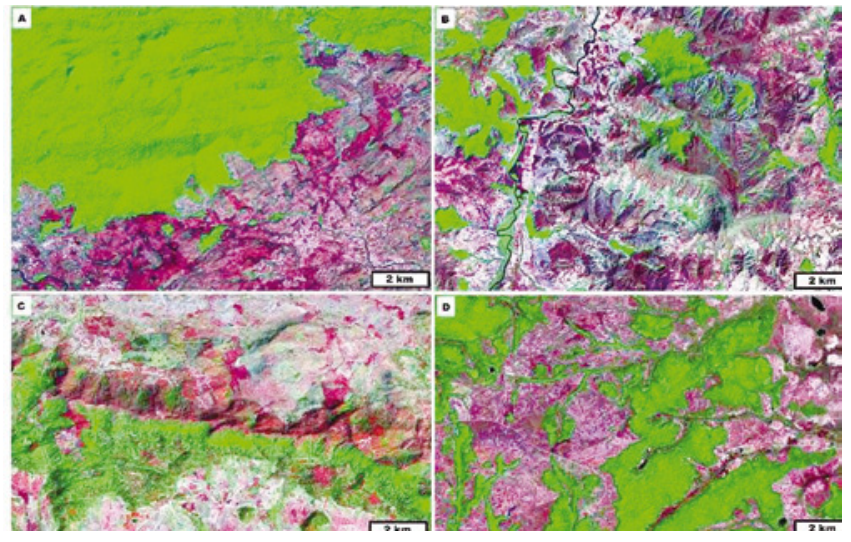

Fig. 7: A - Venezuela-Roraima border, transition of the forest to lavradograssland with tall shrubs and small trees $\left(04^{\circ} 02^{\prime} \mathrm{N}, 61^{\circ} 03^{\prime} \mathrm{W}\right) ; \mathrm{B}-$ Venezuelan open areas, patches of forest with well developed rills and structural control (4 $\left.4^{\circ} 50^{\prime} \mathrm{N}, 60^{\circ} 57^{\prime} \mathrm{W}\right)$; C - Serra da Memória, shrubs and small trees, vegetation slope with tors and blocks $\left(04^{\circ} 10^{\prime} \mathrm{N}, 60^{\circ} 57^{\prime} \mathrm{W}\right)$; D - island vegetation with small lakes at flat plain $\left(3^{\circ} 12^{\prime} \mathrm{N}, 60^{\circ} 57^{\prime} \mathrm{W}\right)$.

Abb. 7: A - Grenze Venezuela - Roraima, Ubergang von Wald zu lavrado - Grasland mit hohen Büschen und niedrigen Bäumen ( $\left.4^{\circ}{ }^{\circ} \mathrm{N}, 61^{\circ} 3^{\prime} \mathrm{W}\right)$; $B$ - Venezuelanische Offenlandschaft mit gut entwickelten Bächen $\left(4^{\circ} 50^{\circ} \mathrm{N}\right.$, $60^{\circ} 57^{\prime} W$ ); C - Serra da Memória, Sträucher und niedrige Bäume, bewachsene Hänge mit Blöcken ( $\left.4^{\circ} 10^{\prime} \mathrm{N}, 60^{\circ} 57^{\prime} \mathrm{W}\right)$; D - inselartige Vegetation mit kleinen Seen in einer flachen Ebene $\left(03^{\circ} 12^{\circ} \mathrm{N}, 60^{\circ} 57^{\circ} \mathrm{W}\right)$.

units comprise the environment where many mammal species can live, such as Myrmecophaga tridactyla (tamanduá) and Tamandua tetradactyla (mambira), two related species of the family Myrmecophagidae (Order Pilosa) that feed on termites and ants. These two mammal species also have the patches of forest as refugia during the night.

Another species that have its habitat associated with the geomorphological units of the open areas is the little mammal Nasua nasua (quati) of the family Procyonidae (Order Carnivora), an inhabitant of the boulders of the plains and hills. During the day it is common to see this animal in that habitat, looking for food, mainly earthworms, insects and some fruits. The vegetation of this habitat is composed by herbs, grasses, scrubs and isolated trees, where $N$. nasua can be found climbed at night. Again, geomorphology gives the direction for describing these habitats.

Among birds we can also have some representative species currently endemic to Roraima, such as Aratinga solstitialis (jandaia-sol) of the family Psittacidae, that live in habitats comprised by the gallery forests or on the forest edge (approximately $03^{\circ} 52^{\prime} \mathrm{N}, 59^{\circ} 37^{\prime} \mathrm{W}$ ). The precise localization of these endangered species habitats can be obtained by geoprocessing techniques, like the other endangered species Synallaxis kollari (joão-de-barba-grisalha) of the family Furnariidae. This small bird can live in habitats formed by low hills and dissected relief, scrubs and small trees, up to the right bank of the Tacutu River, in Guyana territory. Some populations of this bird can also be found in Roraima, in gallery forest.

The same rational can be applied to the botanical species present in the lavrado. For example, there is a small and interesting cactus genus Melocactus that occurs on the rocks forming clusters. The distribution of this cactacean can be easily established through the identification of the rock ex- trusions. Another cactacean present in the lavrado, the distribution of which can be ascertained through geoprocessing techniques, is the Brazilian popular mandacaru genus Cereus, whose main distribution may be associated with the soil, as well with clusters of termite nests genus Cornitermes (approximately $03^{\circ} 52^{\prime} \mathrm{N}, 59^{\circ} 37^{\prime} \mathrm{W}$ ).

It is also very useful and informative to apply the geoprocessing techniques for understanding the lavrado vegetation. These features of the landscape in this area are made up by a complex net of small more or less rounded forest patches (island forests) some 0.5 ha or less, palms trees (linear or almost rounded), described having the focus on the habitat of animals. But we can also focus the question with another lens. How the forest patches of the lavrado are distributed? Is there any pattern accounting for forest patches distribution and soil? The relevance of these questions is not restricted to the present, but imply in considerations such as how the landscape change and what would be the implications for the fauna and flora.

These questions lead us to look at the lavrado vegetation under another focus, which is the pulsation of open and closed vegetal formations under climate changes. It is quite possible that the expansion and retraction of the forest during the Pleistocene have influenced the gene flow of many species living today in these kinds of vegetation, connecting or interrupting definitely or temporarily the patches of forest. How the various species of the lavrado terrestrial vertebrates, for example, were locally affected by the events during the dry and wet paleoclimate periods? What to say about the forest pulsation and climate change that might be undergoing at present?

Recognizing evidence of pulses in the lavrado vegetation, through geoprocessing data associated with the local distribution of species, might certainly elucidate several of these questions. This is the case, for instance, of three sympatric species of lizards of the genus Gymnophthalmus (family Gymnophthalmidae) that occur in the open areas of Roraima and in the forest edge, in contact with the lavrado. The species are $G$. leucomystax associated with termite nests, $G$. vanzoi in the contact forest open areas, and G. underwodii in the continuous forest (VANZOLINI \& CARVALHO 1991; CARVALHO 1999). In a 1.5 kilometer transect, we can find these three lizard species, each one in its specific habitat. These three species are so tightly taxonomically related, that it is difficult to recognize them at a first look, and we can imagine how many geomorphological events might have occurred for the speciation of these three lizards species. We can map the distribution of these lizards through geoprocessing techniques.

Looking again to the landscape of the lavrado and its associated fauna, another example of biogeomorphology applied to the biological distribution of populations comes from the termites. At least two species of these social insects of the family Termitidae build their nests on the ground (epigeous nests): Nasutitermes minimus and the Cornitermes ovatus (BANDEIRA 1988). Both species of termites construct nests in different parts of the lavrado, maybe due to soil factors, vegetation cover or both features together. The nest of N.minus is rounded on the top, around 30-40 centimeters high, and the base is $20-30$ centimeters in diameter, are constructed mainly over the hills (approximately $03^{\circ} 20^{\prime} \mathrm{N}, 61^{\circ} 24 \mathrm{~W}$ ). The 


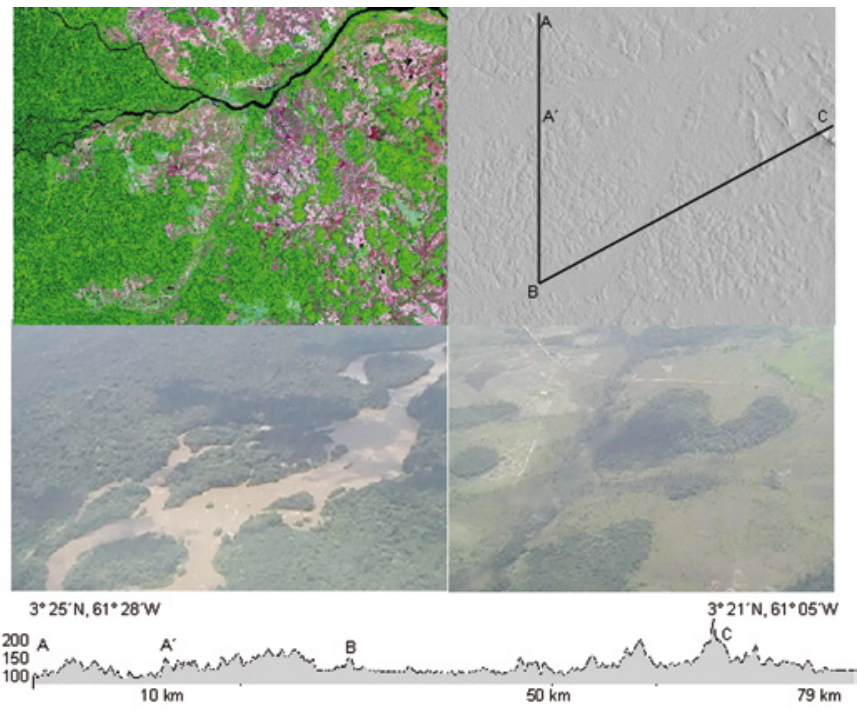

Fig. 8: "A-A'” - Uraricoera River (left photo); B - Grande River; C - Serra do Tabaio. Region of the endemic lizards Gymnophthalmus vanzoi and G. leucomystax (family Gymnophthalmidae). Forest and lavrado contact, with small patches of forest (right photo). Transition of denudational and aggradational relief, with isolated hills, drained by a not well development fluvial plain.

Abb. 8: "A-A"”- Uraricoera (Foto links); B - Grande River; C - Serra do Tabaio. Region mit den endemischen Eidechsen Gymnophthalmus vanzoi und G. leucomystax (Familie Gymnophthalmidae). Wald und lavrado-Kontakt mit kleinen Waldinseln (Foto rechts). Übergang von Abtragungs- zu Aufschüttungsrelief mit isolierten Hügeln, die Entwässerung erfolgt über eine schlecht entwickelte Flussniederung.

nest of C.ovatus is pointed on the top; the construction is very hard, around 2.0 meters high, and the base 1.0-1.5 meters in diameter, mainly constructed on the plains (approximately $03^{\circ} 52^{\prime} \mathrm{N}, 59^{\circ} 37^{\prime} \mathrm{W}$ ), at the same region of the cactacean Cereus.

There are many animals associated to the nests of both of these termite species. The rattlesnake Crotalus ruruima, the lizards Tropidurus hispidus (Family Tropiduridae), Cnemidophorus lemniscatus (Family Teiidae) and the gekko Hemidactyulus mabouia (Family Gekkonidae) are tenants of these nests. Also some species of rats and opossuns, spiders and many invertebrate species live in those nests. There are interesting biological questions associated with the distribution of those termite species. With the help of geoprocessing techniques so as to identify the areas of occurrence of both, nests and soil, any approach related to these termites becomes more practical.

The distribution of rare or endemic species that occur in Roraima can be illustrated on maps using geoprocessing techniques, exemplifying species distributed in the lavrado and surrounding areas of this open vegetation ecosystem (Fig. 8, 9, 10).

\section{Conclusions}

Examples exposed in the present discussion can guide the focus of the biogeomorphology approach in two directions: i) at a regional scale or ii) at a sub-continental level, within or among large vegetal formations. Either way, the questions regarding species and habitats distribution should be made

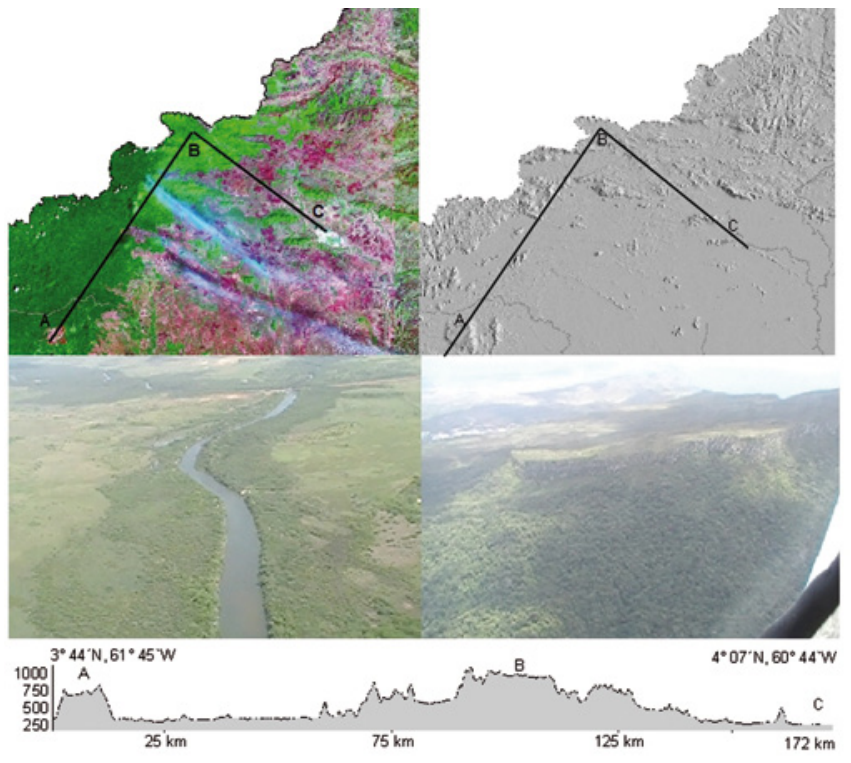

Fig. 9: Brazil-Venezuela border. A - Tepequém tepuy (right photo); BParima River, hills; C - Surumu River (left photo), type locality of the amphibian Elachistocleis surumu. Not well developed fluvial plains (Surumu River), with temporary lakes. Litholic soils with boulders, tors and scrub-herbs vegetation.

Abb. 9: Grenze Brasilien-Venezuela. A - Tepequém tepuy (Foto rechts); B - Parima, Hügel; C - Surumu (Foto links), Typuslokalität der Amphibie Elachistocleis surumu. Schlecht entwickelte Flussniederungen (Surumu) mit temporären Seen. Litholic-Böden mit Felsblöcken, strauch- und krautreiche Vegetation.

involving geomorphology as a backdrop of the whole scenery.

At a sub-continental level, considering large vegetal formations, the questions leads to problems related to speciation and its process. The recognition of the geographic units of the species been studied - the morphoclimatic domains - is fundamental for that approach, because the whole distribution area of a single species or groups of species will be compared through biological aspects, which may vary significantly or not. The main questions that arise at this level may include: How many vegetal formation can be recognized inside the domain (or domains) been studied? How are the soil, topography and hydrography characteristics in each studied region? Are these geomorphic features acting as barriers for gene flow among populations?

At a regional scale, such as that of the lavrado area, before the formulation of specific biological questions it is also imperative to locate the geographic insertion of the region within the main ecosystem. Once recognized the geographic context of the study site, we turn the eyes to the diversity and composition of the regional geomorphological units, such as the boulders, plains, hills, montains, lacustrine system, drainage and regional vegetal formations, which can be done applying remote sensing and geoprocessing techniques.

The geomorphological features will then characterize the habitats. Taking these features as criteria for categorize the compartments of the region, we can focus on the questions to be worked, which can be directed to analyze species richness, regional distribution of a group of species or distribution of a single species, habitat change and modification of 


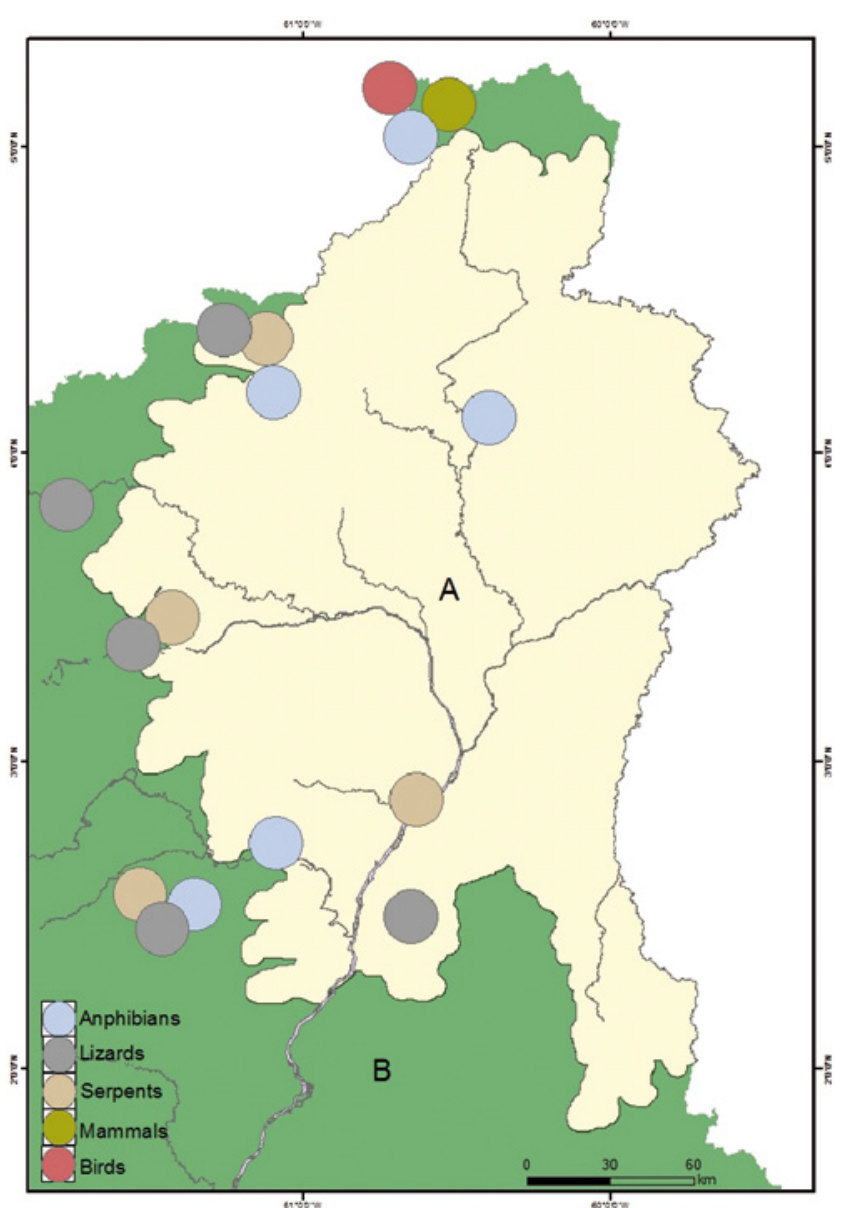

Fig. 10: Distribution of endemic species in northern of Roraima, lavrado. A - Lavrado area; B - Forest area. Some species: Lizards: Mabuya carvalhoi (Sauria: Scincidae), Gymnophthalmus leucomystax (Sauria: Gymnophthalmidae), Gymnophthalmus vanzoi (Sauria: Gymnophthalmidae); Amphibians: Dendropsophus benitezi; Elachistocleis surumu; Serpents:

Micrurus pacaraimae; Birds: Schistocichla saturata ; Herpsilochmus roraimae; Syndactyla roraimae; Myiophobus roraimae; Thamnophilus insignis; Megascops guatemalae; Mammals: Nasua nasua vittata.

Abb. 10: Verteilung endemischer Arten im Norden von Roraima, lavrado. A - Lavrado Bereich; B - Waldbereich. Einige Arten: Echsen: Mabuya carvalhoi (Sauria: Scincidae), Gymnophthalmus leucomystax (Sauria: Gymnophthalmidae), Gymnophthalmus vanzoi (Sauria: Gymnophthalmidae); Amphibien: Dendropsophus benitezi; Elachistocleis surumu; Schlangen: Micrurus pacaraimae; Vögel: Schistocichla saturata ; Herpsilochmus roraimae; Syndactyla roraimae; Myiophobus roraimae; Thamnophilus insignis; Megascops guatemalae; Säugetiere: Nasua nasua vittata.

the landscape, population ecology and conservation. We get these data mainly through inventories, which should start someplace.

If an exhaustive faunal survey is a hard task, because of its high costs and need of experienced personal involvement, a reliable alternative is to select habitat samples by mapping the regional morphoclimatic units. This can be done applying remote sensing and geoprocessing techniques. Where to start will depend on the question. A good set of suggestions can be found in HeYer at al. (1994) and CARvalho (2009) for the lavrado area.

\section{References}

AB’SABER, A.N. (1967): Domínios morfoclimáticos e províncias fitogeográficas do Brasil. - Orientação, 3: 45-48.

Aв’SABER, A.N. (1977): Espaços ocupados pela expansão dos climas secos na América do Sul, por ocasião dos períodos glaciais Quaternários. Orientação, 3: 1-19.

AB'SABER, A.N. (1982): The paleoclimate and paleoecology of Brazilian Amazônia. - In: Prance G.T. (ed.): Biological Diversification in the Tropics: 41-59; New York (Columbia University Press).

AB'SABER, A.N. (1997): A formação Boa Vista: significado geomorfológico e geoecológico no contexto do relevo de Roraima. - In: BARBOSA, R.I., Ferreira E.J.G. \& CASTEllón E.G. (eds.): Homem, ambiente e ecologia no estado de Roraima: 267-293; Manaus (Editora do Inpa).

Ab'Saber, A.N. (2003): Os domínios de natureza no Brasil: Potencialidades paisagísticas. - 159 pp.; São Paulo (Ateliê Editorial).

Absy, M.L. (2000): Fisionomia das savanas de Roraima, Brasil. - Acta Amazonica, 03: 423-440.

Absy, M.L., Cleef, A.M., Fournier, M., Martin, L., Servant, M., Siffedine, A., Silva, M.F.F., Soubies, F., Suguio, K., Turce, B., Hammen, V.D.T. (1991): Mise en évidence de quatre phases d'ouverture de la foret dense dans le sud-est de L'Amazonie au cours des 60,000 dernieres Annees. Premiere Comparaison Avec D'Autres Regions Tropicales. Comptes Rendus de l'Académie des Sciences, 882: 673-678.

BANDEIRA, A.G. (1988): Análise da termitofauna (Insecta: Isoptera) de uma floresta primária e de uma pastagem na Amazônia Oriental, Brazil. Boletim Museu Paraense Emílio Goeldi, 5: 225-241.

BeIgbeder, Y. (1959): La région moyenne du haut rio Branco (Brésil): Étude géomorphologique. - 254 pp; Université de Paris, Institut National de Recherches de L'Amazonie.

Carvalho, C.M. (2009): O lavrado da Serra da Lua em Roraima e perspectivas de estudos da herpetofauna na região. - Revista Geografica Acadêmica, 3: 4-17.

CARvalHo, T.M. (2009a): Parâmetros geomorfométricos para descrição do relevo da Reserva de Desenvolvimento Sustentável do Tupé, Manaus, Amazonas. - In: Nelson, E. ¿ Scudeller, V. (eds.): Biotupé: Meio Físico, Diversidade Biológica e Sociocultural do Baixo Rio Negro, Amazônia Central: 3-17; Manaus (Amazonas)

Carvalho, T.M. \& RAmirez, R. (2008): Técnicas de sensoriamento remoto aplicadas à biogeografia: metodologia geográfica para espacialização de moluscos terrestres. - Boletim Goiano de Geografia, 28: 157-166.

CARvalho, T.M., Zucchi, M. (2009): Morfometria e caracterização do meio físico de ambientes lacustres no Vão do Paranã-Goiás, Brasil: uma primeira aproximação. - Terra Nueva Etapa, 38: 111-138.

Coutinho, L.M. (1978): O conceito de cerrado. - Revista Brasileira de Botânica, 1: 17-23.

Ducke, A \& Blake G.A. (1953): Phytogeographical notes on the Brazilian Amazon. - Anais da Academia Brasileira de Ciências, 19: 1-46.

Egler, W. A. (1960): Contribuição ao conhecimento dos campos da Amazônia. I - Os campos do Ariramba. - Boletim do Museu Paraense Emilio Goeldi, 4: 1-36.

Eiten, G. (1963): Habitat flora of fazenda Campininha, São Paulo, Brazil. - In: Ferri, M.G. (ed.): Simpósio sobre o cerrado: 179-231; São Paulo (Editora da Universidade de São Paulo).

EITEN, G. (1992): How names are used for vegetation. - Journal of Vegetation Science, 3: 419-424.

Eiten, G. (1994): Vegetação do cerrado. - In: Pinto, M.N. (ed.): Cerrado: caracterização, ocupação e perspectivas: 17-73; Distrito Federal E(ditora da Universidade de Brasília).

HAFFer, J. (1969): Speciation in Amazonian forest birds. - Science, 3889: 131-137.

Haffer, J. \& Prance, G.T. (2001): Climatic force of evolution in Amazonia during the Cenozoic: On the refuge theory of biotic differentiation. Amazoniana, 16: 579-607.

Hammond, D.S. (2005): Ancient land in a modern world. In: HAmmond, D.S. (ed.): Tropical forest of the Guiana Shield: 1-14; Washington (DC) (CABI Publishing).

Heyer, W.R., Donnelly, M.A., McDiamid, R.H., Hayek, L.A.C. \& Foster, M.S. (1994): Measuring and monitoring biological diversity. - In: Standards methods for amphibians: 384; Washington (DC) (Smithsonian Institution Press).

Heyer, W.R. (1995): South American rocky habitat Leptodactylus (Amphibia: Anura: Leptodactylidae) with description of two new species. - Proceedings of the Biological Society of Washington, 108: 695-716.

Hiruma, S.T. (2007). Revisão dos conhecimentos sobre o significado das linhas de seixos. - Revista do Instituto Geológico, 2: 53-64. 
Murça Pires, J. (1974): Tipos de vegetação da Amazônia. - Brasil Florestal, 17: 48-58.

Metzger, J.P. (1997): Relationship between landscape structure and tree species diversity in tropical forests of South-East Brazil. - Landscape Urban Planning, 37: 29-35.

NAscimento, S.P. (1998): Ocorrência de lagartos no lavrado de Roraima (Sauria: Teiidae: Gekkonidae: Iguanidae: Polychrotidae: Tropiduridae: Scincidae e Amphisbaenidae), Brasil. - Boletim do Museu Integrado de Roraima, 4: 39-49.

Nunes, A. \& Bobadilha, U. (1997): Mamíferos de Roraima: status da diversidade e conservação. - In: BARbosA, R.I., FERreira, E.J.G., CASTELlóN E.G. (eds): Homem, ambiente e ecologia no estado de Roraima: 565-579; Manaus (Editora do Inpa).

Pessenda, L.C.R., Oliveira, P., Mofatto, M., Garcia, R. Aravena, R., LeIte, A.Z. (2009): The evolution of a forest/grassland mosaic since 28,000 C-14 yr BP based on pollen and carbon isotopes. - Quaternary Research, 71: 437-452.

PiAnKA, E. R. (1994): Evolutionary Ecology. 5th: 486; New York (Harper Collins).

Ruellan, F. (1957): Expedições geomorfológicas no Território do Rio Branco: $170 ; \mathrm{CNPq}$ - Rio de Janeiro (Inpa).

RADAmbRAsil (1975): Levantamento de Recursos Naturais. - Volume 8. Fol ha NA 20 e parte da Folha NA 21 Tumucumaque - NB 20 Roraima e NB 21: geologia, geomorfologia, pedologia, vegetação e uso potencial da terra: 428 pp.; Rio de Janeiro (Departamento Nacional de Produção Mineral).

Rafael, J.A., Rafael, M.S., Henriques, A.L. (1997): Notas sobre insetos de Roraima. - In: Barbosa, R.I., Ferreira, E.J.G., CAstellón, E.G. (eds) Homem, ambiente e ecologia no estado de Roraima: 489-508; Manaus (Editora do Inpa)
SAlgado-Laboriau, M.L. (1982): Climatic change at the PleistoceneHolocene boundary. - In: PrAnce, G.T. (ed.): Biological diversification in the tropics: 74-77; New York (Columbia University Press).

VANZolini, P.E. (1970): Zoologia sistemática, geografia e a origem das espécies. - Série Teses e Monografias, 3: 1-56.

VANZOLINI, P.E. (1981): A quasi-historical approach to the natural history of the differentiation of reptiles in tropical geographic isolates. - Papéis Avulsos de Zoologia, 34 (19): 189-204.

VANZOLINI, P.E. (1988): Distributional patterns of South American lizards. - In: Heyer W.R., \& VAnzolini, P.E. (eds): Proceedings of a workshop on Neotropical distribution patterns: 317-342; Rio de Janeiro Academia (Brasileira de Ciências).

VAnzolini, P.E. (1992): Paleoclimas e especiação em animais da América do Sul tropical. - Estudos Avançados, 15: 41-65.

VANZolini, P.E. \& Williams, E.E. (1970): South American anoles: the geographic differentiation and evolution of the Anolis chrisolepis species group (Sauria, Iguanidae). - Arquivos de Zoologia, 19: 1-298.

VAnzolini, P.E. \& CARvalho, C.M. (1991): Two sibling and sympatric species of Gymnophthalmus in Roraima, Brasil (Sauria:Teiidae). - Papéis Avulsos de Zoologia, 37: 173-226.

Victoria, R.L., Martinelli, L.A., Cunha, H.B., Richey, J.E. (2000): The Amazon basin and its natural cycles. - In: SAlati, E., ABsy, M.A., VICTORIA, R.L. (eds.): Amazônia: Um ecossistema em transformação: 163214; Manaus (Inpa).

Wüster, W., Ferguson, J., Quijada-Mascarenas, A., Pook, C., Salomão, M., Thorpe, R. (2005): Tracing an invasion: landbridges, refugia, and the phylogeography of the Neotropical rattlesnake (Serpentes: Viperidae: Crotalus durissus). - Molecular Ecology, 14: 1-14. 